\title{
Aflatoxin M1 Contamination of Milk and Its Products in Bomet County, Kenya
}

\author{
Gladys Langat', Matsusawa Tetsuhiro², Tohru Gonoi², Vivienne Matiru3 ${ }^{3}$, Christine Bii ${ }^{4}$ \\ ${ }^{1}$ Institute of Tropical Medicine and Infectious Diseases, Jomo Kenyatta University of Agriculture and \\ Technology, Nairobi, Kenya \\ ${ }^{2}$ Medical Mycology Research Center, Chiba University, Chiba, Japan \\ ${ }^{3}$ Department of Botany, Sub-Department of Medical Microbiology, Jomo Kenyatta University of Agriculture and \\ Technology, Nairobi, Kenya \\ ${ }^{4}$ Centre of Microbiology Research, Kenya Medical Research Institute, Nairobi, Kenya \\ Email: tetiobeto@gmail.com
}

Received 10 May 2016; accepted 24 June 2016; published 27 June 2016

Copyright (C) 2016 by authors and Scientific Research Publishing Inc.

This work is licensed under the Creative Commons Attribution International License (CC BY). http://creativecommons.org/licenses/by/4.0/

(c) (i) Open Access

\section{Abstract}

Aflatoxin M1 (AFM1) is a major carcinogenic compound that may be found in milk and dairy products resulting from ingestion of aflatoxin B1 by dairy animals. The study aimed at determining the level of aflatoxin M1 in milk and milk products from Bomet County. A total of 185 samples (150 raw milk and 35 processed milk and milk products) were randomly collected from milk collection sites and randomly selected milk kiosks respectively. The AFM1 was analyzed using a commercial ELISA kit (Ridascreen, aflatoxin M1 R-Biopharm, Product code, R5812, Darmstadt, Germany). Out of 185 samples investigated, 156 samples were positive for AFM1, an overall contamination rate of $84.32 \%$. The samples with levels higher than the tolerance limit of $0.05 \mu \mathrm{g} / \mathrm{l}$ recommended by Food and Agriculture Organization (FAO) and World Health Organization (WHO) limits were $43.8 \%$ mainly contributed by the raw milk compared to processed milk $(52.0 \%$ versus 8.6\%). Processed milk had insignificant level of contamination with aflatoxin M1 (Median 0.00 (IQR: $0.00,0.00 \mu \mathrm{g} / \mathrm{l}$ ) with a minimum of $0.00 \mu \mathrm{g} / \mathrm{l}$ and a maximum of $0.69 \mu \mathrm{g} / \mathrm{l}$. Raw milk showed significant contamination, median 0.09 (IQR: $0.00,0.50$ ) $\mu \mathrm{g} / \mathrm{l}$ with a minimum of $0.00 \mu \mathrm{g} / \mathrm{l}$ and a maximum of $2.93 \mu \mathrm{g} / \mathrm{l}$. Although there was no significant differences in AFM1 levels with study sites ( $P=0.217)$; the median levels of aflatoxin $M 1$ was high in sites 1,3 , and 7 . The sites that had median aflatoxin M1 levels below the WHO/FAO acceptable limits of $0.05 \mu \mathrm{g} / \mathrm{l}$ were sites 2, 4 and 6 . Due to high incidence of AFM1 contamination of milk and milk samples in Bomet County, there is need for regular monitoring and regulation of AFM1 contamination in milk and its products in the County. 
Keywords

Aflatoxin M1, ELISA, Milk, Products, Bomet

\section{Introduction}

Mycotoxins are toxic fungal secondary metabolites that if ingested can cause a variety of adverse effects on both humans and animals [1]. Aflatoxins are toxic compounds produced mainly as secondary metabolites by Aspergillus flavus and Aspergillus parasiticus [2]. Aspergillus species are capable of growing on a diversity of substrates under a variety of environmental conditions mainly in tropical and subtropical climates thus aflatoxins occur as natural contaminants in many agricultural commodities [3] and can be produced during growth, harvesting and storage [4]. The most frequent aflatoxins are B1, B2, G1 and G2. Aflatoxin B1 (AFB1) is the most common and toxic one and has been reported as the most powerful natural carcinogen in human and animals [5] [6]. Aflatoxin M1 (AFM1) or milk toxin is a hydroxylated metabolite of aflatoxin B1 and is secreted in milk of dairy cattle after consumption of feed contaminated with aflatoxin B1 [7] [8]. Studies have shown that AFM1 could quickly appear (within 12 hour) after ingestion of AFB1 by lactating cows [9] and its concentration decreased gradually to under the limit of detection within $72 \mathrm{~h}$ after removal of AFB1 contaminated feeds [10]. The International Agency for Research on Cancer has classified AFB1 and AFM1 as class 1 human carcinogens [11]. Aflatoxin M1 has been well known to have cytotoxic, genotoxic, and carcinogenic effects [9] [12]. Human exposure to AFM1 is due to the consumption of contaminated milk and dairy products of which daily intake could be highly variable in the world. Infants represent the most susceptibly exposed population due to their high consumption of dairy products either as cow's milk and related by-products in their diet or from breast milk where the mycotoxin can be excreted. The Joint FAO/WHO Expert Committee on Food Additives [13] reported that the intake of AFM1 from milk was $6.8 \mathrm{ng} /$ person/day for the European diet, $3.5 \mathrm{ng} / \mathrm{person} /$ day for the Latin American diet, 12 ng/person/day for the Far Eastern diet, 0.7 ng/person/day for the Middle Eastern diet and 0.1 ng/person/day for the African diet.

To exclude the possible toxicity for humans several countries have set up maximum acceptable limits of AFM1 in milk and its by-products which vary from the $50 \mathrm{ng} / \mathrm{kg}$ established by the EU to the $500 \mathrm{ng} / \mathrm{kg}$ established by US FDA [14]. Contamination of milk and milk products with AFM1 varies with the geography and development level of a country. The contamination levels of AFM1 can be differentiated further by hot and cold seasons due to the fact that grass, pasture, weed and rough feeds are found more commonly in spring and summer than in winter [15]. The consumption of cow's milk is highly popular among the people of Bomet however; little information exists on the occurrence of AFM1 in milk and milk products.

\section{Materials and Methods}

\subsection{Collection of Milk Samples}

Between December, 2014 and March 2015, a total of 185 milk samples were collected from different locations in Bomet County, Kenya. Approximately $250 \mathrm{ml}$ of the milk samples were collected. Raw milk was collected from individual farmers as they brought their milk to the collection centres. The samples were collected in sterile screw capped bottles. Processed milk and milk products were purchased from randomly selected milk kiosks. The milk samples were transported in ice packets in a coolbox and stored at $-20^{\circ} \mathrm{C}$ in case of delay. Analysis was performed in Mycology Lab at the Kenya Medical Research Institute.

\subsection{Sample Preparation for AFM1 Detection}

The samples were allowed to thaw at room temperature, and then centrifuged at $3500 \mathrm{rpm}$ for 10 minutes. The upper cream layer was then removed by aspirating with a Pasteur pipette. Fifty microliters of the milk samples were used directly for AFM1 assay.

\subsection{Quantitative Determination of AFM1 by ELISA Technique}

The samples were analyzed for AFM1 using the direct competitive ELISA (RIDASCREEN Aflatoxin M1, RBiopharm, Art. No.: R5812). The method used is quick, reliable and cost effective for estimation of AFM1 in 
milk and has been included in the official collection of test procedures by the German Federal Board of Health. Sufficient number of microtiter wells was inserted into the microwell holder for all standards and samples to be run. Briefly, $50 \mu$ l of standard solutions (0 ppt, 125 ppt, 250 ppt, 500 ppt, 1000 ppt and 2000 ppt) and prepared samples were added into microtitre wells using new pipette tip for each standard or sample. Exactly 50 $\mu \mathrm{l}$ of enzyme conjugate (peroxidase) was then added to each well. Another $50 \mu \mathrm{l}$ of anti-aflatoxin M1 was added into each well and mixing done gently by shaking the plate followed by incubation for $10 \mathrm{~min}$ at room temperature. The liquid was then poured out of the wells and the microwell holder tapped upside down onto a clean filter towel to remove all remaining liquid from the wells. Washing with washing buffer (250 $\mu 1)$ twice then followed. The wells were emptied to remove all the remaining liquid. After that, $100 \mu$ of substrate/ chromogenic solution (tetramethylbenzidine) was added to the wells, mixed gently by shaking the plate and incubated for $5 \mathrm{~min}$ at room temperature in the dark. Finally, $100 \mu \mathrm{l}$ of the stop solution was added into the wells mixed gently by shaking the plate and immediately measured the absorbance at $450 \mathrm{~nm}$ in ELISA plate reader.

\subsection{Calculation of AFM1 Concentration}

The absorbance values obtained for the standards and the samples was divided by the absorbance value of the first standard (zero standards) and multiplied by 100 (percentage maximum absorbance). The zero standard was thus made equal to $100 \%$, and the absorbance values quoted in percentages. The percentage of the absorbance values obtained for the standards were plotted on semilogarithmic graph paper against the aflatoxin M1 standards concentration in parts per billion.

\subsection{Statistical Analysis}

Data was analyzed using STATA version 13 SE. Gaussian assumptions for the continuous variables were assessed empirically using Shapiro-Wilk test and graphically using normal probability plots. Violation of the assumptions triggered summaries using median and the corresponding interquartile ranges (IQR) as well as the minimum and the maximum values. Categorical variables were summarized as frequencies and the corresponding percentages. Association between categorical variables was assessed using Pearson’s Chi Square test.

\section{Results}

\subsection{Occurrence of Aflatoxin M1 in Examined Milk Samples}

The results of the analyses of AFM1 level ( $\mu \mathrm{g} / \mathrm{l})$ in raw and processed milk and milk products are shown in Table 1 . The presence of AFM1 was observed in $84.3 \%$ of all samples. The overall prevalence of aflatoxin M1 contamination beyond the WHO/FAO threshold limit of $0.05 \mu \mathrm{g} / \mathrm{l}$ was $43.8 \%$. This was contributed mainly by the raw milk which was $52.0 \%$ compared processed milk with $8.6 \%$. The difference was statistically significant, $\mathrm{P}<0.0001$. From the table it is clear that there was $100 \%$ aflatoxin M1 contamination of raw milk; $52 \%$ above and $48 \%$ below the WHO/FAO threshold limit of $0.05 \mu \mathrm{g} / \mathrm{l}$ respectively. The overall median was 0.02 (IQR: $0.00,0.40) \mu \mathrm{g} / \mathrm{l}$ which is below the acceptable limits.

\subsection{Levels of Aflatoxin M1 in Milk Samples}

Processed milk did not show any evidence of contamination, median 0.00 (IQR: 0.00, 0.00) $\mu \mathrm{g} / \mathrm{l}$ with a minimum of $0.00 \mu \mathrm{g} / \mathrm{l}$ and a maximum of $0.69 \mu \mathrm{g} / \mathrm{l}$ while the raw milk showed evidence of aflatoxin M1 contamination, median 0.09 (IQR: 0.00, 0.50) $\mu \mathrm{g} / \mathrm{l}$ with a minimum of $0.00 \mu \mathrm{g} / \mathrm{l}$ and a maximum of $2.93 \mu \mathrm{g} / \mathrm{l}$ (Table 2).

Table 1. Occurrence of aflatoxin M1 in raw and processed milk samples.

\begin{tabular}{cccc}
\hline Contamination & Raw & Processed & Total \\
\hline Concentration $>0.05 \mu \mathrm{g} / 1$ & $78(52 \%)$ & $3(8.6 \%)$ & $81(43.8 \%)$ \\
$0<$ Concentration $<0.05 \mu \mathrm{g} / 1$ & $72(48 \%)$ & $3(8.6 \%)$ & $75(40.5 \%)$ \\
Total & $150(100 \%)$ & $6(17.1 \%)$ & $156(84.3 \%)$ \\
\hline
\end{tabular}




\subsection{Occurrence of AFM1 in Raw Milk Samples across Sites}

Aflatoxin M1 occurrence in milk across sites showed site 3 samples as highly contaminated (73.1\%), compared to the other sites. Clearly, raw milk contributed the highest levels of contamination. Site 4 had low prevalence, $37.5 \%$ compared to the others however the test for differences was not statistically significant, $\mathrm{P}=0.217$ (Table 3).

\subsection{Levels of Aflatoxin M1 in Raw Milk Samples across Sites}

The median levels of aflatoxin M1 was high in sites 1, 3, and 7. However, these sites showed some evidence of samples that were not contaminated (minimum $=0.0$ ). The sites that had median aflatoxin M1 levels below the WHO/FAO acceptable limits of $0.05 \mu \mathrm{g} / \mathrm{l}$ were sites 2, 4 and 6 (Table 4). However, looking at the corresponding maximum aflatoxin levels shows evidence that some samples were highly contaminated based on the threshold value of $0.05 \mu \mathrm{g} / \mathrm{l}$.

Table 2. Aflatoxin M1 levels in processed and raw milk products.

\begin{tabular}{|c|c|c|c|c|c|c|}
\hline State of Milk & No. of Samples & Median & Lower Quartile & Upper Quartile & Minimum & Maximum \\
\hline Raw & 150 & 0.09 & 0.00 & 0.50 & 0.00 & 2.93 \\
\hline Processed & 35 & 0.00 & 0.00 & 0.00 & 0.00 & 0.69 \\
\hline Total & 185 & 0.02 & 0.00 & 0.40 & 0.00 & 2.93 \\
\hline
\end{tabular}

Table 3. Occurrence of aflatoxin M1 levels in raw milk across sites.

\begin{tabular}{ccc}
\hline Contamination & Concentration $>0.05 \mu \mathrm{g} / 1$ & $0<$ Concentration $<0.05 \mu \mathrm{g} / 1$ \\
SITE 1 & $7(50.0 \%)$ & $7(50.0 \%)$ \\
SITE 2 & $6(40.0 \%)$ & $9(60.0 \%)$ \\
SITE 3 & $19(73.1 \%)$ & $7(26.9 \%)$ \\
SITE 4 & $6(37.5 \%)$ & $10(62.5 \%)$ \\
SITE 5 & $14(48.3 \%)$ & $15(51.7 \%)$ \\
SITE 6 & $11(44.0 \%)$ & $14(56.0 \%)$ \\
SITE 7 & $15(60.0 \%)$ & $10(40.0 \%)$ \\
\hline
\end{tabular}

Table 4. Aflatoxin M1 levels in raw milk collected from seven sites.

\begin{tabular}{|c|c|c|c|c|c|c|}
\hline SITES & No. of Samples & Median & Lower Quartile & Upper Quartile & Minimum & Maximum \\
\hline SITE 1 & 14 & 0.14 & 0.00 & 0.88 & 0.00 & 1.16 \\
\hline SITE 2 & 15 & 0.02 & 0.00 & 0.29 & 0.00 & 0.93 \\
\hline SITE 3 & 26 & 0.54 & 0.03 & 0.86 & 0.00 & 2.93 \\
\hline SITE 4 & 16 & 0.01 & 0.00 & 0.15 & 0.00 & 0.44 \\
\hline SITE 5 & 29 & 0.04 & 0.00 & 0.44 & 0.00 & 0.93 \\
\hline SITE 6 & 25 & 0.00 & 0.00 & 0.48 & 0.00 & 0.80 \\
\hline SITE 7 & 25 & 0.10 & 0.00 & 0.22 & 0.00 & 0.81 \\
\hline Total & 150 & 0.09 & 0.00 & 0.50 & 0.00 & 2.93 \\
\hline
\end{tabular}




\subsection{Occurrence and Levels of Aflatoxin M1 in Processed Milk}

The prevalence of aflatoxin M1 contamination in the processed milk was low 8.6\% and was contributed mainly by fermented milk (50.0\%) and yoghurt (37.5\%). There was no statistically significant difference in the level of contamination between fermented (processed) milk and yoghurt (Table 5).

\subsection{Levels of Aflatoxin M1 in Processed Milk}

There was no evidence of contamination in processed fresh milk and UHT. However, fermented milk as well as the yoghurt showed evidence of contamination with maximum values above $0.05 \mu \mathrm{g} / \mathrm{l}$ (Table 6).

\section{Discussion}

Milk is a valuable source of nutrients widely used in many countries however; it can be a risk for exposure to toxic compounds such as mycotoxins [16]. According to this study, the occurrence of AFM1 in milk was high with $84.3 \%$ of all the examined samples contaminated Table 1 . The overall prevalence of aflatoxin M1 contamination beyond the WHO/FAO threshold limit of $0.05 \mu \mathrm{g} / \mathrm{l}$ was $43.8 \%$. This was contributed mainly by the raw milk which was $52.0 \%$ compared to processed milk with $8.6 \%$. There was $100 \%$ aflatoxin M1 contamination of raw milk; $52 \%$ above and $48 \%$ below the WHO/FAO threshold limit of $0.05 \mu \mathrm{g} / \mathrm{l}$ respectively. The difference in contamination levels between processed and raw milk samples was statistically significant, $(\mathrm{P}<0.0001)$. Many other researchers have reported the occurrence of high levels of AFM1 in numerous countries that exceeded maximum allowed limits in milk [7] [17]-[22]. A more recent study in the Greater Addis Ababa reported a high incidence of AFM1 in milk where over 90\% of the milk samples contained aflatoxin M1 levels exceeding the European Union limit of $0.05 \mu \mathrm{g} / \mathrm{l}$ [23]. Previous studies by [24] and [25] recorded lower incidences of AFM1 in milk in comparison to this with samples above the EU maximum limits at $36.2 \%$, $20 \%$ and $5 \%$ respectively. Studies conducted in Kenya in fresh milk collected from urban centers had levels that were lower comparable to present study where only $20 \%$ of the milk from dairy farmers had levels exceeding WHO/FAO levels of 0.05 ppb [26].

Raw milk samples showed evidence of Aflatoxin M1 contamination, median 0.09 with a minimum of 0.00 $\mu \mathrm{g} / \mathrm{l}$ and a maximum of $2.93 \mu \mathrm{g} / \mathrm{l}$. The higher prevalence rate (100\%) along with moderately higher contamination level of AFM1 in the raw milk samples indicate that lactating cows in Bomet are exposed to AFB1-contaminated feeds in different study sites. However, it was not possible to determine the level of AFB1 in the feed of dairy cattle in the present study. Bomet County is usually characterized by high temperature and humidity between the months of January and March which was the period for our sample collection. These conditions are

Table 5. Occurrence of aflatoxin M1 in different types of processed milk.

\begin{tabular}{cccc}
\hline Contamination & Fermented & Yoghurt & P-value \\
\hline Concentration $>0.05 \mu \mathrm{g} / 1$ & $1(16.7 \%)$ & $2(25.0 \%)$ & $1.000^{\mathrm{f}}$ \\
$0<$ Concentration $<0.05 \mu \mathrm{g} / 1$ & $2(33.3 \%)$ & $1(12.5 \%)$ & \\
Concentration $=0.00 \mu \mathrm{g} / 1$ & $3(50.0 \%)$ & $5(62.5 \%)$ & \\
\hline
\end{tabular}

Table 6. Aflatoxin M1 levels in different types of processed milk products.

\begin{tabular}{cccccc}
\hline $\begin{array}{c}\text { Processed Milk and } \\
\text { Milk products }\end{array}$ & No of Samples & Median & Lower Quartile & Upper Quartile & Minimum \\
\hline Fermented Milk & 6 & 0.00 & 0.00 & 0.00 & 0.00 \\
Fresh Milk & 15 & 0.00 & 0.00 & 0.00 & 0.00 \\
UHT & 6 & 0.00 & 0.00 & 0.00 & 0.00 \\
Yoghurt & 8 & 0.00 & 0.00 & 0.00 & 0.00 \\
Total & 35 & 0.00 & 0.00 & 0.00 & 0.00 \\
\hline
\end{tabular}


favorable for growth and proliferation of aflatoxin producing fungi. It is a common practice for farmers to give supplementary feeds in form of spoilt grains and commercial feeds to their cattle besides grazing. Fungi may easily produce toxins in inappropriate storage conditions. It has been reported that environmental temperature, humidity and moisture content of the feed as well as $\mathrm{pH}$ and mechanical damage to cereal grains resulted in higher AFB1 in animal feeds [19]. Following the consumption of AFB1 contaminated feed by dairy cattle, AFB1 is converted to AFM1 in the liver and results in contamination of milk of lactating cows with aflatoxin M1.

Aflatoxin M1 contamination in milk across seven milk collection sites showed site 3 samples as highly contaminated (73.1\%), compared to the other sites. Site 4 had the least prevalence, 37.5\% compared to the others however the test for differences was not statistically significant, $\mathrm{P}=0.217$ Table 3 . The median levels of aflatoxin M1 was high in sites 1, 3, and 7. However, these sites showed some evidence of samples that were not contaminated (minimum $=0.0$ ). The sites that had median aflatoxin M1 levels below the WHO/FAO acceptable limits of $0.05 \mu \mathrm{g} / \mathrm{l}$ were sites 2, 4 and 6 Table 4. The wide variations in AFM1 levels among sites/studies could be related to geographic and climatic differences, but the most important could be the differences in feeding systems and farm management practices [17]. The conversion of dietary AFB1 into milk AFM1 also varies widely among animal breeds, days, and from one milking session to the next and it is greatly influenced by physiological factors such as diet and health status of animals, especially the status of the liver and its enzymatic activities.

This study also showed that processed milk samples had low contamination levels (8.6\%) contributed mainly by fermented milk (50.0\%) and yoghurt (37.5\%). Both fresh processed milk and UHT had no contamination. Generally, processed milk did not show any evidence of contamination, median 0.00 with a minimum of 0.00 $\mu \mathrm{g} / \mathrm{l}$ and a maximum of $0.69 \mu \mathrm{g} / \mathrm{l}$ Table 5 \& Table 6 . This could be attributed to the treatment effects of raw milk which could have lowered the concentration of aflatoxin M1 in the processed samples. According to studies on the effect of various heat treatments on AFM1 content of cow's milk, it was reported that sterilization of milk at $121^{\circ} \mathrm{C}$ for 15 min caused $12.21 \%$ degradation of AFM1, whereas boiling decreased AFM1 by $14.50 \%$ [27]. It was concluded that destruction of AFM1 depends on time and temperature combination of the heat treatment applied. In another study by [28], it was observed that pasteurization caused a decrease in the level of AFM1 at the rate of $7.62 \%$. Other studies [29] showed that pasteurization can partially reduce the amount of AFM1 in milk. However, some reports show that aflatoxins are stable during heat-treatments such as pasteurization and sterilization [30]. The effect of fermentation was assessed by [31]. It was reported that AFM1 levels in all yoghurt samples showed a significant decrease from those initially present in milk. This could be attributed to factors such as low $\mathrm{pH}$, formation of organic acids or other fermentation by-products, and even to the presence of lactic acid bacteria [4].

Majority of the residents in the study area consume raw cow's milk and traditionally fermented milk (mursik) and less of processed milk and its products. Mursik is mainly produced by the Kalenjin community in Kenya, through spontaneous fermentation of cow's milk in a traditionally prepared gourd [32] [33]. It forms a major part of the Kalenjin diet due to its delicious taste and belief that it improves health [32]. There is therefore need for a survey involving a larger number of processed milk and milk products.

In comparison to this study, other studies have showed no AFM1 detected in processed milk samples examined in various countries, such as Argentina [34], Japan [35] and Turkey [36]. The occurrence of AFM1 in UHT commercial milk in Portugal was investigated where only two UHT-treated milk exceeded the set limit while the other 68 UHT-treated samples had low levels [37]. Moreover, lower findings were reported in other countries such as Turkey [38] and Iran [9]. Higher contamination was however reported by other authors [39][43]. In Portugal [18] and Italy [44], yoghurt samples were also contaminated with low levels of AFM $_{1}$.

Several studies indicate that exposure to AFM1 has a possible link to an increased risk of developing cancer in humans [45]. The carcinogenicity of AFM1 may be influenced by the duration and level of exposure. Exposure is most likely to occur through the frequent consumption of milk and milk among foods because of the AFM1 associated with the by-products (infant milk, cheese, yoghurt) [46].

\section{Conclusions}

The results of this study show that the presence of aflatoxin (AFM1) in the examined milk appears to be a serious public health hazard, indicating a need for the periodical monitoring of AFM1 in the raw milk and milk 
products. It is important to prevent toxin production in feed, as well as create effective detoxification processes thus further studies are required to measure the level of AFB1 in the rations of supplementary feeds given to lactating cows in relation to the level of AFM1 in milk.

Implementing a food supervision control system in the dairy products industries, and application of strict regulations by the national government and other food control agencies, also frequent analytical surveillance are required to control the incidence of aflatoxin in dairy products in Kenya.

\section{Acknowledgements}

I would like to extend my gratitude to the Centre of Microbiology in Kenya Medical Research Institute personnel for availing the laboratory space and the equipment. I am greatly indebted to Professor Gonoi of Chiba University for providing the kits for AFM1 quantifications and NACOSTI for funding the mycotoxin study facilities at KEMRI.

\section{Conflict of Interest}

There is no conflict of interest from other co-others in the publication of this manuscript in this journal. All the co-others have contributed in the preparation of the manuscript up to the submission stage.

\section{Ethical Approval}

Approved by KEMRI's Scientific Steering Committee (SSC) and Ethical Review Committee (ERC); SSC Protocol Number 2890.

\section{References}

[1] Hampikyan, H., Baris Bingol, E., Cetin, O. and Colak, H. (2010) Determination of Aflatoxin M1 Levels in Turkish White, Kashar and Tulum Cheeses. Journal of Food Agriculture and Environment, 13-15.

[2] Baskaya, R., Aydin, A., Yildiz, A. and Bostan, K. (2006) Aflatoxin M1 Levels of Some Cheese Varieties in Turkey. Medycyna Wet, 62, 778-780.

[3] Kensler, T., Roebuck, B., Wogan, G. and Groopman, J. (2011) Aflatoxin: A 50-Year Odyssey of Mechanistic and Translational Toxicology. Toxicological Sciences, 120, S28-S48.

[4] Prandini, A., Tansini, G., Sigolo, S., Filippi, L., Laporta, M. and Piva, G. (2009) On the Occurrence of Aflatoxin M1 in Milk and Dairy Products. Food Chemical Toxicology, 47, 984-991. http://dx.doi.org/10.1016/j.fct.2007.10.005

[5] Hussain, I., Anwar, J., Munawar, M.A. and Asi, M.R. (2008) Variation of Levels of Aflatoxin M1 in Raw Milk from Different Localities in the Central Areas of Punjab, Pakistan. Food Control, 19, 1126-1129. http://dx.doi.org/10.1016/j.foodcont.2007.12.002

[6] Torkar, K.G. and Vengust, A. (2008) The Presence of Yeasts, Moulds and Aflatoxin M1 in Raw Milk and Cheese in Slovenia. Food Control, 19, 570-577. http://dx.doi.org/10.1016/j.foodcont.2007.06.008

[7] Dashti, B., Al-Hamli, S., Alomirah, H., Al-Zenki, S., Bu Abbas, A. and Sawaya, W. (2009) Levels of Aflatoxin M1 in Milk, Cheese Consumed in Kuwait and Occurrence of Total Aflatoxin in Local and Imported Animal Feed. Food Control, 20, 686-690. http://dx.doi.org/10.1016/j.foodcont.2009.01.001

[8] Iha, M.H., Barbosa, C.B., Okada, I.A. and Trucksess, M.W. (2013) Aflatoxin M1 in Milk and Distribution and Stability of Aflatoxin M1 during Production and Storage of Yoghurt and Cheese. Food Control, 29, 1-6. http://dx.doi.org/10.1016/j.foodcont.2012.05.058

[9] Fallah, A. (2010) Aflatoxin M1 Contamination in Dairy Products Marketed in Iran during Winter and Summer. Food Control, 21, 1478-1481. http://dx.doi.org/10.1016/j.foodcont.2010.04.017

[10] Rahimi, E. and Karim, G. (2008) Determination of Aflatoxin M1 in Raw Milk Producing in Dairy Farms in Chahar-Mahal-Bakhtiari Province Using ELISA. The Journal of Food Science and Technology, 5, 51-59.

[11] International Agency for Research on Cancer (IARC) (2002) Aflatoxins. IARC Monograph on the Evaluation of Carcinogenic Risks to Humans. Vol. 82, IARC, World Health Organization, Lyon, 171.

[12] Awad, W.A., Ghareeb, K. and Böhm, J. (2012) Occurrence, Health Risks and Methods of Analysis for Aflatoxins and Ochratoxin A. Journal of Veterinary and Animal Sciences, 2, 1-10.

[13] JECFA (2001) Fifty-Sixth Meeting of the Joint FAO/WHO Expert Committee on Food Additives. Safety Evaluation of Certain Mycotoxins in Food. Food Additive Series, World Health Organization, Geneva, 47. 
[14] Reverberi, M., Ricelli, A., Zjalic, S., Fabbri, A.A. and Fanelli, C. (2010) Natural Functions of Mycotoxins and Control of Their Biosynthesis in Fungi. Applied Microbiology and Biotechnology, 87, 899-911. http://dx.doi.org/10.1007/s00253-010-2657-5

[15] Alborzi, S., Pourabbas, B., Rashidi, M. and Astaneh, B. (2006) Aflatoxin M1 Contamination in Pasteurized Milk in Shiraz (South of Iran). Food Control, 17, 582-584. http://dx.doi.org/10.1016/j.foodcont.2005.03.009

[16] Ghazani, M.H.M. (2009) Aflatoxin M1 Contamination in Pasteurized Milk in Tabriz (Northwest of Iran). Food and Chemical Toxicology, 47, 1624-1625. http://dx.doi.org/10.1016/j.fct.2009.04.011

[17] Motawee, M., Meyer, K. and Bauer, J. (2004) Incidence of Aflatoxins M1 and B1 in Raw Milk and Some Dairy Products in Damietta, Egypt. Journal of Agriculture Science (Mansoura-Egypt), 29, 711-718.

[18] Hussain, I. and Anwar, J. (2008) A Study on Contamination of Aflatoxin M1 in Raw Milk in the Punjab Province of Pakistan. Food Control, 19, Article ID: 393395.

[19] Amer, A. and Ibrahim, M. (2010) Determination of Aflatoxin M1 in Raw Milk and Traditional Cheeses Retailed in Egyptian Markets. Journal of Toxicology and Environmental Health Sciences, 2, 50-53

[20] Kamkar, A., JahedKhaniki, G. and Alavi, S. (2011) Occurrence of Aflatoxin M1 in Raw Milk Produced in Ardabil of Iran. Iran. Journal of Environmental Health Science \& Engineering, 8, 123-128.

[21] Panahi, P., Kasaee, S., Mokhtari, A., Sharifi, A. and Jangjou, A. (2011) Assessment of Aflatoxin M1 Contamination in Raw Milk by ELISA in Urmia, Iran. American Eurasian Journal of Toxicological Sciences, 3, 231-233.

[22] Tsakiris, I., Tzatzarakis, M., Alegakis, A., Vlachou, M., Renieri, E. and Tsatsakis, A. (2013) Risk Assessment Scenarios of Children'S Exposure to Aflatoxin M1 Residues in Different Milk Type from the Greek Market. Food \& Chemical Toxicology, 56, 261-265. http://dx.doi.org/10.1016/j.fct.2013.02.024

[23] Gizachew, D., Szonyi, B., Tegegne, A., Hanson, J. and Grace, D. (2016) Aflatoxin Contamination of Milk and Dairy Feeds in the Greater Addis Ababa Milk Shed, Ethiopia. Food Control, 59, 773-779. http://dx.doi.org/10.1016/j.foodcont.2015.06.060

[24] Al Zuheir, I. M. and Abu Omar, J. (2012) Presence of Aflatoxin M1 in Raw Milk for Human Consumption in Palestinian. Walailak Journal of Science and Technology, 9, 375-382.

[25] Duarte, S.C., Almeida, A.M., Teixeira, A.S., Pereira, A.L., Falcão, A.C., Pena, A., et al. (2013) Aflatoxin M1 in Marketed Milk in Portugal, Assessment of Human and Animal Exposure. Food Control, 30, 411-417. http://dx.doi.org/10.1016/j.foodcont.2012.08.002

[26] Kangethe, E.K. and Langat, K.A. (2009) Aflatoxin B1 and M1 Contamination of Animal Feeds and Milk from Urban Centers in Kenya. African Health Sciences, 9, 218-226.

[27] Choudhary, P.L., Sharma, R.S. and Borkartria, V.N. (1998) Effect of Chilling and Heating on Aflatoxin M1 Content of Contaminated Indian Cow’s Milk. Egyptian Journal of Dairy Science, 223-229.

[28] Sinha, K.K. (1998) Detoxification of Mycotoxins and Food Safety. In: Sihna, K.K. and Bhatnagar, D., Eds., Mycotoxins in Agriculture and Food Safety, Marcel-Dekker, New York, 381-406.

[29] Deveci, O. (2007) Changes in the Concentration of Aflatoxin M1 during Manufacture and Storage of White Pickled Cheese. Food Control, 9, 1103-1107. http://dx.doi.org/10.1016/j.foodcont.2006.07.012

[30] Govaris, A., Roussi, V., Koidis, A. and Botsoglou, N.A. (2001) Distribution and Stability of Aflatoxin M1 during Processing, Ripening and Storage of Telemes Cheese. Food Additives and Contaminants, 18, 437-443. http://dx.doi.org/10.1080/02652030120550

[31] Govaris, A., Roussi, V., Koudis, P.A. and Botsoglou, N.A. (2002) Distribution and Stability of Aflatoxin M1 during Production and Storage of Yoghurt. Food Additives and Contaminants, 19, 1043-1050. http://dx.doi.org/10.1080/0265203021000007831

[32] Mathara, J.M., Miyamoto, T., Koaze H., Kiiyukia, C. and Yoneya, T. (1995) Production of Traditional Fermented Milk in Kenya. A Review, 257-263.

[33] Food and Agriculture Organization (FAO) of the United Nations, Rome (1990) The Technology of Traditional Milk Products in Developing Countries. FAO Animal Production and Health, Paper 85, Rome, Italy.

[34] Lopez, C.E., Ramos, L.L., Ramadan, S.S. and Bulacio, L.C. (2003) Presence of Aflatoxin M1 in Milk for Human Consumption in Argentina. Food Control, 14, 31-34. http://dx.doi.org/10.1016/S0956-7135(02)00049-X

[35] Tabata, S., Kamimura, H., Ibe, A., Hashimoto, H., Iidia, M., Tamura, Y. and Nishima, T. (1993) Aflatoxin Contamination in Foods and Foodstuffs in Tokyo, 1986-1990. Journal of AOAC International, 76, 32-35.

[36] Oruc, H.H. and Sonal, S. (2001) Determination of Aflatoxin M Levels in Cheese and Milk Consumed in Bursa. Veterinary and Human Toxicology, 43, 292-293.

[37] Martins, M.L. and Martins, H.M. (2004) Aflatoxin M1 in Yoghurts. Portugal International Journal of Food Microbi- 
ology, 91, 315-317. http://dx.doi.org/10.1016/S0168-1605(02)00363-X

[38] Unusan, N. (2006) Occurrence of Aflatoxin M1 in Uht Milk in Turkey. Food and Chemical Toxicology, 44, 18971900. http://dx.doi.org/10.1016/j.fct.2006.06.010

[39] Gundinc, U. and Filazi, A. (2009) Detection of Aflatoxin M1 Concentrations in UHT Milk Consumed in Turkey Markets by ELISA. Pak. Journal of Biological Sciences, 12, 653-656. http://dx.doi.org/10.3923/pjbs.2009.653.656

[40] Atasever, M., Adiguzel, G., Özlü, H. and Özturan, K. (2010) Occurrence of Aflatoxin M1 in UHT Milk in Erzurum-Turkey. Kafkas Üniversitesi Veteriner Fakültesi Dergisi, 16, S119-S122.

[41] Kamkar, A. (2008) Detection of Aflatoxin M1 in UHT Milk Samples by ELISA. Journal of Veterinary Research, 63, 7-12.

[42] Tekinşen, K.K. and Eken, H.S. (2008) Aflatoxin M1 Levels in UHT Milk and Kashar Cheese Consumed in Turkey. Food and Chemical Toxicology, 46, 3287-3289. http://dx.doi.org/10.1016/.fct.2008.07.014

[43] German, C.S., Sonia, M., Antonio, J., Ramos, J., Vicente, P. and Vicente, S. (2010) Occurrence of Aflatoxin M1 and Exposure Assessment in Catalonia (Spain). Revista Iberoamericana de Micología, 27, 130-135.

www.elsevier.es/reviberoammicol http://dx.doi.org/10.1016/j.riam.2010.05.003

[44] Galvano, F., Galofaro, V., Ritienis, A., Bognanno, M., De Angelis, A. and Galvano, G. (2001) Survey of the Occurrence of Aflatoxin $M_{1}$ in Dairy Products Marketed in Italy, Second Year of Observation. Food Additives and Contaminants, 20, 644-646. http://dx.doi.org/10.1016/j.riam.2010.05.003

[45] Wogan, G.N., Hecht, S.S., Felton, J.S., Conney, A.H. and Loeb L.A. (2004) Environmental and Chemical Carcinogenesis. Seminars in Cancer Biology, 14, 473-486. http://dx.doi.org/10.1016/j.semcancer.2004.06.010

[46] Caloni, F., Stammati, A., Friggè, G. and De Angelis, I. (2006) Aflatoxin M1 Absorption and Cytotoxicity on Human Intestinal in Vitro Model. Toxicon, 47, 409-415. http://dx.doi.org/10.1016/j.toxicon.2005.12.003

\section{Submit or recommend next manuscript to SCIRP and we will provide best service for you:}

Accepting pre-submission inquiries through Email, Facebook, Linkedin, Twitter, etc

A wide selection of journals (inclusive of 9 subjects, more than 200 journals)

Providing a 24-hour high-quality service

User-friendly online submission system

Fair and swift peer-review system

Efficient typesetting and proofreading procedure

Display of the result of downloads and visits, as well as the number of cited articles

Maximum dissemination of your research work

Submit your manuscript at: http://papersubmission.scirp.org/ 